\title{
Fecal Collection and Stabilization Methods for Improved Fecal DNA Test for Colorectal Cancer in a Screening Setting
}

\author{
Francesca Maria Carozzi and Cristina Sani \\ ISPO, Cancer Prevention and Research Institute, Analytical and Biomolecular Cytology Unit, Via Cosimo il Vecchio 2, \\ 50139 Florence, Italy \\ Correspondence should be addressed to Cristina Sani; c.sani@ispo.toscana.it
}

Received 10 April 2013; Revised 24 July 2013; Accepted 11 August 2013

Academic Editor: Mario Scartozzi

Copyright ( 2013 F. M. Carozzi and C. Sani. This is an open access article distributed under the Creative Commons Attribution License, which permits unrestricted use, distribution, and reproduction in any medium, provided the original work is properly cited.

\begin{abstract}
Early detection of CRC and adenomas reduces CRC-related mortality. The optimal screening test for CRC is still a subject of debate, and molecular stool sample analysis could provide a valid alternative to conventional methods in terms of compliance and practicability. Seven fecal DNA storage systems were evaluated in two successive phases. In the first phase of the study was selected the preservative buffer able to ensure the best human DNA recovery. In the second phase was evaluated human DNA stability, amplificability and integrity in DNA extracted from selected buffer. Results showed that the best performance was obtained in samples stored in $100 \mathrm{mM}$ EDTA buffer and Genefec buffer. Likewise buffer addition yielded a significant increase in DNA stability and integrity without PCR inhibition, compared to the matched aliquots with no buffer added. Our study shows that samples collected in stabilization solution stabilize DNA so that intact nucleic acids, are more effectively detectable in the molecular assay. DNA buffer preservation and storage conditions could be useful to guarantee the most consistent yield in human DNA. Stabilization buffer addition to stool samples prior to transport presents an easily implemented solution that appears to be highly effective. Overall DNA extracted from faeces preserved in preservative buffer can feasibility been used for molecular analysis leading to an increase of assay sensitivity.
\end{abstract}

\section{Introduction}

Colorectal cancer (CRC) is one of the most common malignancies worldwide. CRC is the third leading cause of cancerrelated mortality and the second leading cause of cancerrelated incidence. Nevertheless, the survival rate of patients with CRC is high if this cancer can be diagnosed and surgically resected at an early stage [1]. Early detection of CRC reduces CRC-related mortality, and removal of its precursor lesions (adenomas) reduces both the incidents and mortality of CRC [2]. Thus, population screening of asymptomatic average risk persons is arguably the most effective intervention for preventing any cancer, and it has great potential to reduce morbidity and mortality [2-6]. Currently, several possible screening techniques are available and recommended by scientific societies: guaiac and immunochemical faecal occult blood test (FOBT), sigmoidoscopy, colonoscopy, computed tomography colonography (CT colonography or CTC), and faecal DNA test [7]. FOBT has been used widely as a screening test for CRC [1]. Randomized clinical trials demonstrated that screening with FOBT reduces mortality from CRC [3, 4]. Moreover, faecal immunochemical test showed better sensitivity-specificity ratio and cost-effectiveness than guaiac test $[8-10]$.

However, three large-scale studies have shown that the sensitivity of a faecal occult blood test was not very high when a total colonoscopy in all subjects was used as a reference standard [11-13]. Colonoscopy and CT colonography are pancolonic examinations. Colonoscopy is widely accepted as the clinical reference standard for detection of colorectal neoplasia. Up to date, there is no evidence about the reduction of mortality for CRC with colonoscopy screening. Indirect data show that this strategy could reduce the incidence for CRC from 76 to $90 \%$ [2]. Theoretical screening with colonoscopy 
in selected cohorts of subjects offers the possibility to detect and remove most of advanced adenomas and thus to prevent a lot of cancers, allowing long screening intervals (more than 10 years). The major disadvantages of colonoscopy as a screening method are its complications, including bleeding and perforation and burdensome due to preparation and procedure [14]. Due to this issue attendance to colonoscopy as primary screening test is quite low [15].

CT colonography is a minimally invasive full colonic examination. CTC has been demonstrated to have high sensitivity for the detection of CRC in a meta-analysis (96\%) [16]. In two large trials conducted on asymptomatic individuals at average risk for CRC, CTC showed high per-patient sensitivity for adenomas larger than $10 \mathrm{~mm}$, respectively, 92.2\% and 90\%. Per-patient specificities for adenomas larger than $10 \mathrm{~mm}$ were, respectively, $96 \%$ and $86 \%[17,18]$. The diagnostic yield for advanced neoplasia of CT colonography $(3,2 \%)$ was comparable to that colonoscopy $(3,4 \%)$ [19]. The risk of complications from CTC is extremely low, in particular in screening subjects [20]. The optimal screening test for CRC is still a subject of debate. FOBT and FS have been shown to reduce mortality for CRC. However, they are not pancolonic examinations, and their ability to detect adenomas is not completely satisfactory. In Italy FOBT based screening programs are available in several regions [21]. A population screening program for CRC has been acting in Tuscany region since 2000 . The screening protocol is directed to all subjects aged 50-70 living in the regional area who are invited via mail every second year to perform immunochemical FOBT. Subjects with negative FOBT are notified of their result by mail and advised to repeat screening after two years. Subjects with positive test are invited to perform colonoscopy [22].

In this contest, molecular stool sample analysis might offer a noninvasive test and could provide a valid alternative to conventional methods in terms of compliance (increasing screening compliance by individuals who are reluctant to undergo more invasive tests such as colonoscopy) and practicability (reducing the number of colonoscopy with a minimal loss of important lesions).

Many studies have shown that individual molecular alterations are present in the stool of only a fraction of patients and are therefore characterized by low sensitivity in detecting colorectal cancer [23-27]. New tests based on molecular modification, able to detect neoplastic cells or cell products in stool, are currently under evaluation. A variety of genetic and epigenetic alterations, which commonly occur during evolution from normal colon mucosa to adenoma and carcinoma, such as K-ras, p53, APC gene mutations, microsatellite instability pathway (Bat 25, Bat 26, and Bat 40), DNA integrity (DIA), or epigenetic events such as promoter methylation (Vimentin, SFRP2) have become recognized as a key pathway by which colon cancers develop [2, 2832]. Nevertheless one of the major obstacles to introduce faecal markers in population screening studies has been the difficulty in collecting adequate samples. In fact faecal samples collection procedures must be chosen in a way that (1) allows maximizing the recovery of human DNA from samples, (2) preserves human DNA in stool preventing human nucleic acid degradation, thereby potentially limiting clinical sensitivity and ensuring DNA integrity, (3) limits the action of inhibitory factors present in stool that could inhibit PCR efficiency.

Recent studies show that samples collected in a stabilization solution stabilize the DNA so that intact nucleic acids indicative of diseased cells are more effectively detected in the molecular assay. Nucleic acids in patient samples tend to degrade after they have been removed from the patient. This degradation can diminish the yield in human DNA and effectiveness of the molecular assay. Storage methodologies must be able to efficiently select the rare human component, and because the mutant copies (when present) represent only a small percentage of the total DNA in stool, it is important to maximize the recovery of human DNA and to preserve the DNA in stool such that it does not degrade during sample handling [33]. The addition of a DNA-stabilizing buffer to the stool immediately after defecation was shown to prevent DNA degradation for several days and enhance the performance of molecular tests [34-36].

Several methods to ensure that DNA remains stable are evaluated in the literature such as to freeze stool sample as quickly as possible after collection [30] or addition of stabilization buffer $[33,34]$.

In the present feasibility study, multiple methods for faecal DNA preservation were tested in order to evaluate the effect of sample-handling condition on recoverable DNA. This approach could allow the use of molecular assay as an efficient and accurate, noninvasive test in the colorectal cancer screening setting.

\section{Materials and Methods}

2.1. Study Population. The study population consisted in healthy volunteers that were thoroughly informed about the study. All samples were stored, coded, and manipulated anonymously by researchers.

2.2. Study Design. Given that the purpose of the study was to evaluate the best method of samples recovery and stabilization in order to facilitate the procedures for sample delivery after collection and to allow the use of fecal DNA molecular tests in screening programs, several stabilisation buffers were evaluated. Aim of the study was to investigate the influence of buffer addition to complex samples, such as stool, and to preserve DNA so as to allow patients to collect the stool in the preservative buffer and to return to the laboratory not necessarily as soon as possible.

Storage systems used in this study were: Buffer EDTA 20 mM, Buffer EDTA 100 mM, RNAlater RNA Stabilization Reagent (Qiagen); Cytolyte (ThinPrep, Cytyc Corporation); Buffer Genefec (NORDIAG); Buffer $\alpha$-Wasserman and refrigerator storage that were subsequently evaluated in two successive phases. In the first phase of the study was selected the preservative buffer able to ensure the best human DNA recovery. On these selected buffers in the second phase will be evaluated human DNA stability, amplificability, and integrity. 
Phase 1. Phase 1 is based on the evaluation of the best method of stool collection able to ensure the best yield in genomic DNA.

Seven healthy donor were asked to collect faecal samples and deliver them in the laboratory within two hours from collection. Prior to starting the incubation time course, stool samples were aliquoted standardized by weight $(500 \mathrm{mg})$.

2.3. Samples Preparation. For each sample, $0.5 \mathrm{~g}$ aliquots (at least five for each preservative method) were removed by taking cores of the stool sample. Each $0.5 \mathrm{~g}$ core received one of the preservative treatments, which included

\section{A: Refrigerator storage; \\ B: Buffer EDTA 100 mM (Zou et al. [37]); \\ C: Buffer Genefec (NORDIAG); \\ D: Buffer EDTA $20 \mathrm{mM}$ (Zou et al. [37], Olson et al.} [33]);

E: RNAlater RNA Stabilization Reagent (Qiagen) (Nechvatal et al. [34]);

F: Cytolyte (ThinPrep, Cytic Corporation);

G: Buffer $\alpha$-Wasserman.

In the case of buffer addition, two mL of buffer was simply added to the stool aliquot in a plastic container with the lid, and the sample was homogenized. One aliquot $(0 \mathrm{H})$ of each preservative treatment was immediately frozen and served as incubation controls.

For each sample aliquots were frozen at different times $(24 \mathrm{H}, 72 \mathrm{H}$ and $120 \mathrm{H})$ and stored at room temperature until the freezing time. It was, however, maintained freeze on unpreserved stool (A refrigerator storage) because we felt that this could represent the comparison method on which to base subsequent evaluations. Unpreserved stool were frozen at times $0 \mathrm{H}, 24 \mathrm{H}$, and $72 \mathrm{H}$ (Table 1).

All preservation methods incorporated a "hold" period at ambient temperature to mimic the likely delay between selfcollection of a sample and receipt by an analytical laboratory, for comparison with alternative storage procedures utilizing $24 \mathrm{~h}$ refrigeration or immediate freezing.

In all samples evaluation of alternative storage procedures was assessed comparing the genomic DNA recovery by absolute quantification in real-time PCR of $\beta$-globin, gene and the mean yield for each preservative buffer was calculated.

Phase 2. Assess human DNA stability, amplificability, and integrity in sample stored in two different preservative buffers (Buffer EDTA $100 \mathrm{mM}$ and Buffer Genefec) compared with unpreserved frozen faeces. For this purpose, we extracted DNA from stool and evaluated the quality of the samples by determining the success rates for human DNA yield, PCR amplification, and DNA usefulness for molecular analysis. The panel included genomic DNA quantification performed in real-time PCR on $\beta$-globin gene, DNA amplificability and integrity through the use of primers that amplify fragments of different size.
TABLE 1: Summary of stool samples preservation.

\begin{tabular}{|c|c|c|}
\hline Buffer & Hold time* $^{*}$ & Number of samples \\
\hline \multirow{4}{*}{ A Refrigerator storage } & Fresh $(0 \mathrm{H})$ & 7 \\
\hline & $24 \mathrm{H}$ & 7 \\
\hline & $36 \mathrm{H}$ & 7 \\
\hline & $72 \mathrm{H}$ & 7 \\
\hline \multirow{5}{*}{ B Buffer EDTA $100 \mathrm{mM}$} & Fresh $(0 \mathrm{H})$ & 7 \\
\hline & $24 \mathrm{H}$ & 7 \\
\hline & $36 \mathrm{H}$ & 7 \\
\hline & $72 \mathrm{H}$ & 7 \\
\hline & $120 \mathrm{H}$ & 7 \\
\hline \multirow{5}{*}{ C Buffer Genefec } & Fresh $(0 \mathrm{H})$ & 7 \\
\hline & $24 \mathrm{H}$ & 7 \\
\hline & $36 \mathrm{H}$ & 7 \\
\hline & $72 \mathrm{H}$ & 7 \\
\hline & $120 \mathrm{H}$ & 7 \\
\hline \multirow{5}{*}{ D Buffer EDTA $20 \mathrm{mM}$} & Fresh $(0 \mathrm{H})$ & 7 \\
\hline & $24 \mathrm{H}$ & 7 \\
\hline & $36 \mathrm{H}$ & 7 \\
\hline & $72 \mathrm{H}$ & 7 \\
\hline & $120 \mathrm{H}$ & 7 \\
\hline \multirow{5}{*}{$\begin{array}{l}\text { E RNAlater RNA } \\
\text { Stabilization Reagent }\end{array}$} & Fresh $(0 \mathrm{H})$ & 7 \\
\hline & $24 \mathrm{H}$ & 7 \\
\hline & $36 \mathrm{H}$ & 7 \\
\hline & $72 \mathrm{H}$ & 7 \\
\hline & $120 \mathrm{H}$ & 7 \\
\hline \multirow{5}{*}{ F Cytolyte } & Fresh $(0 \mathrm{H})$ & 7 \\
\hline & $24 \mathrm{H}$ & 7 \\
\hline & $36 \mathrm{H}$ & 7 \\
\hline & $72 \mathrm{H}$ & 7 \\
\hline & $120 \mathrm{H}$ & 7 \\
\hline \multirow{5}{*}{ G Buffer $\alpha$-Wasserman } & Fresh $(0 \mathrm{H})$ & 7 \\
\hline & $24 \mathrm{H}$ & 7 \\
\hline & $36 \mathrm{H}$ & 7 \\
\hline & $72 \mathrm{H}$ & 7 \\
\hline & $120 \mathrm{H}$ & 7 \\
\hline
\end{tabular}

${ }^{*}$ The old time is the amount of time the sample is held in preservative prior to transfer to $-80^{\circ} \mathrm{C}$ freezer.

2.4. DNA Extraction. Total DNA was extracted from stool samples with QIAamp DNA Stool Mini Kit (Qiagen) following the instruction of the manufacturer with same modification. DNA was finally eluted in $200 \mathrm{~mL}$ buffer AE.

2.5. Real-Time $\beta$-Globin PCR. To get an estimate of the quantity of human DNA present in our samples was carried out a real-time PCR on human $\beta$-globin gene. The sequences of the probe and the primers used are as follows: probe FAMTCT GCC GTT ACT GCC C-NFQ, forward primer $5^{\prime}$-AGC AAC CTC AAA CAG ACA CCA T-3', reverse primer $5^{\prime}$ CCA ACT TCA TCC ACG TTC ACC TT-3'. The reaction 
TABLE 2: PCR primer set of genes analyzed to assess DNA amplificability and integrity.

\begin{tabular}{|c|c|c|c|c|}
\hline Region & Forward primer & Reverse primer & $\begin{array}{l}\text { Product size } \\
\text { (bp) }\end{array}$ & $\begin{array}{c}\text { Annealing } \\
\text { temperature } \\
\left({ }^{\circ} \mathrm{C}\right)\end{array}$ \\
\hline KRAS & ACTGAATATCTTGTGGTAGTTGGAGCT & TCAAAGAATGGTCCTGGACC & 157 & 54 \\
\hline ТP53 ex 6 & CTGGAGAGACGACAGGGCTG & GACAACCACССТTAАССССТС & 219 & 60 \\
\hline TP53 ex 7 & $\begin{array}{l}\text { CTTGCCACAGGTCTCCCCAA } \\
\text { CGCCCGCCGCGCCCCGCGCCCGTCCCG }\end{array}$ & TCAGCGGCAAGCAGAGGCTG & 233 & 60 \\
\hline TP53 ex 8 & $\begin{array}{l}\text { CCGCCCCCGCCCGACTGCCTCTTGCTTCTC } \\
\text { TTTTCC }\end{array}$ & AATCTGAGGCATAACTGCACCC & 271 & 62 \\
\hline NRAS & GTCACTTTAAGAACCAAATGG & GAGAGACAGGATCAGGTCA & 288 & 54 \\
\hline NRAS & CTTGGCAATAGCATTGTATTC & GATTCAGAACACAAAGATCATC & 315 & 54 \\
\hline TP53 ex 5 & GCTGCCGTGTTCCAGTTGC & TCAGTGAGGAATCAGAGGCC & 330 & 60 \\
\hline KRAS & GTTGAGTTGTATATAACACC & ATTATATGCATGGCATTAGC & 343 & 54 \\
\hline
\end{tabular}

mixture for each reaction consisted of a template, $1,25 \mu \mathrm{L}$ 20X Assay mix $\beta$-globin, $12.5 \mu \mathrm{L}$ of TaqMan Universal Master mix 2X (Applied Biosystem) in a total reaction volume of $25 \mu \mathrm{L}$. Real-time PCR amplification was performed with precycling heat activation of DNA polymerase at $50^{\circ} \mathrm{C}$ for $2 \mathrm{~min}$, followed by 40 cycles of denaturation at $95^{\circ} \mathrm{C}$ for $15 \mathrm{~s}$, annealing at $60^{\circ} \mathrm{C}$ for $1 \mathrm{~min}$, in a 7500 real-time system (Applied Biosystems). The absolute equivalent amount of DNA in each sample was determined by use of a calibration curve with serial dilutions ( $5 \mathrm{ng}, 0.5 \mathrm{ng}, 0.25 \mathrm{ng}$, and $0.05 \mathrm{ng}$ ) of genomic DNA "human DNA male" (10 ng/ $\mu \mathrm{L})$ (Applied Biosystems). A negative control (without template) was run in each reaction plate.

2.6. DNA Amplification. DNA of samples stored in preservative buffer was also amplified to assess the possibility to use it for molecular analysis. We target 8 regions from 2 genes (p53 and Ras). Eight different primers set that amplified fragments of $157 \mathrm{bp}$ between $343 \mathrm{bp}$, used to amplified those regions, and the annealing temperatures are showing in Table 1. PCR reactions contained $5 \mu \mathrm{L} 10 \mathrm{X}$ PCR Buffer I (Applied Biosystem), $4 \mu \mathrm{L}$ dNTPs (Roche), $2.5 \mu \mathrm{L}$ of each primer, $0.3 \mu \mathrm{L} 5 \mathrm{U} / 1$ Taq Gold (Applied Biosystem), $5 \mu \mathrm{L}$ template DNA, and $30.7 \mu \mathrm{L}$ water to fill the final reaction volume to $50 \mu \mathrm{L}$. The PCR protocol began with an initial denaturation step of $94^{\circ} \mathrm{C}$ for $9 \mathrm{~min}$, followed by 40 cycles of $94^{\circ} \mathrm{C}$ denaturation for $60 \mathrm{~s}$; temperature varies according to the primers pair used primer annealing for $60 \mathrm{~s}$ (Table 1), and $72^{\circ} \mathrm{C}$ extension for $60 \mathrm{~s}$; and a final $72^{\circ} \mathrm{C}$ elongation step for $10 \mathrm{~min}$. PCR products were verified via $2 \%$ agarose gel(s).

In each group (Table 2) of fecal samples obtained from the volunteers, PCR amplification for each of the 8 regions was conducted for the genomic DNA template extracted from stool. In addition, control PCR product was obtained by amplifying human genomic DNA (Applied Biosystems). A negative control (without template) was run in each reaction. All PCR products were analyzed by gel electrophoresis.

\section{Results}

3.1. Phase 1. For each sample, amounts of genomic DNA in fresh faeces at $0 \mathrm{H}$ were compared with genomic DNA recovered in each stabilization buffer: Buffer EDTA $20 \mathrm{mM}$, Buffer EDTA 100 mM, RNAlater RNA Stabilization Reagent (Qiagen), Cytolyt (ThinPrep, Cytic Corporation), Buffer Genefec (NORDIAG), and Buffer $\alpha$-Wasserman. In detail, after calculating the DNA recovery for fresh faeces $0 \mathrm{H}$ and set this value as $100 \%$, the yield of genomic DNA for the preservative buffer was calculated as

$$
\frac{[\text { Amount of genomic DNA buffer } 0 \mathrm{H}]}{[\text { Amount of genomic DNA of fresh faeces } 0 \mathrm{H}]} \times 100 \text {. }
$$

Results showed that at $0 \mathrm{H}$, total amounts of genomic DNA extracted from samples stored with different preservative buffer varied considerably. Buffer $\alpha$-Wasserman, buffer EDTA $20 \mathrm{mM}$, Cytolyt, and RNAlater RNA Stabilization Reagent (Qiagen) consistently gave lower yields than fresh faeces. All samples preserved with buffer EDTA $20 \mathrm{mM}$, Cytolyt, and RNAlater RNA Stabilization Reagent (Qiagen) yielded less than $50 \%$ of DNA recovered in fresh faeces while all samples preserved with Buffer $\alpha$-Wasserman had mild loss of recovery yielding around $20 \%$ less of DNA recovered in fresh faeces, then these buffers were immediately discarded (Figure 1).

Results showed that at $0 \mathrm{H}$ the best performance was obtained in samples stored in $100 \mathrm{mM}$ EDTA buffer and Genefec buffer (278.91\% and 373.4\%), respectively.

3.2. Phase 2 Genomic DNA Stability. In the second phase, on the basis of first phase results, genomic DNA stability of sample stored in Buffer EDTA $100 \mathrm{mM}$ and in Buffer Genefec was compared with genomic DNA stability in stool sample unpreserved but directly frozen, because we felt that they could represent the comparison method on which to base subsequent evaluations.

Results obtained in samples stored at different freezing times showed that EDTA $100 \mathrm{mM}$ buffer maintains a greater sample stability over time compared to Buffer Genefec and directly frozen samples. The absolute best performance is obtained with $100 \mathrm{mM}$ EDTA buffer frozen after $24 \mathrm{H}$ (Figure 2).

DNA yield on frozen faeces showed that without any buffer addiction, already at $24 \mathrm{H}$, yielded less than $50 \%$ of the 


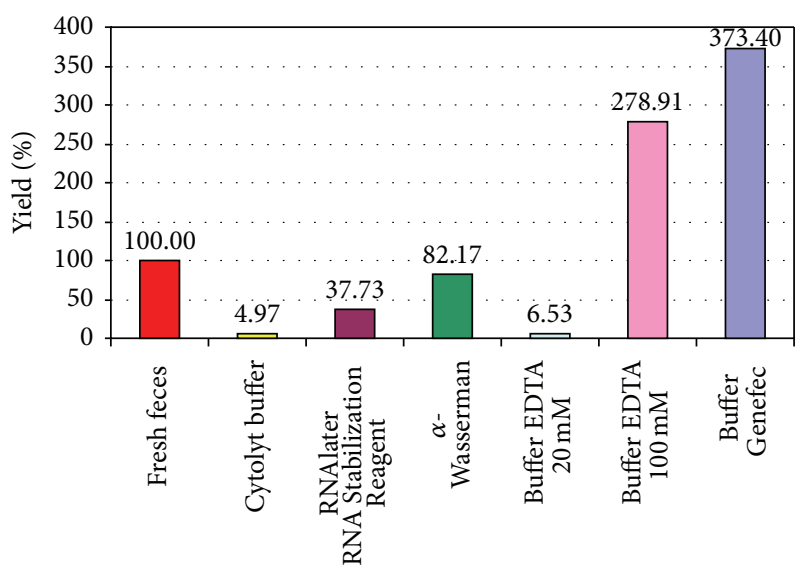

FIGURE 1: Quantification of recoverable human DNA from seven samples incubated with or without stabilization buffer. Mean yields at $0 \mathrm{H}$ of human DNA, expressed as percentage, in several preservative buffers compared to fresh feces.

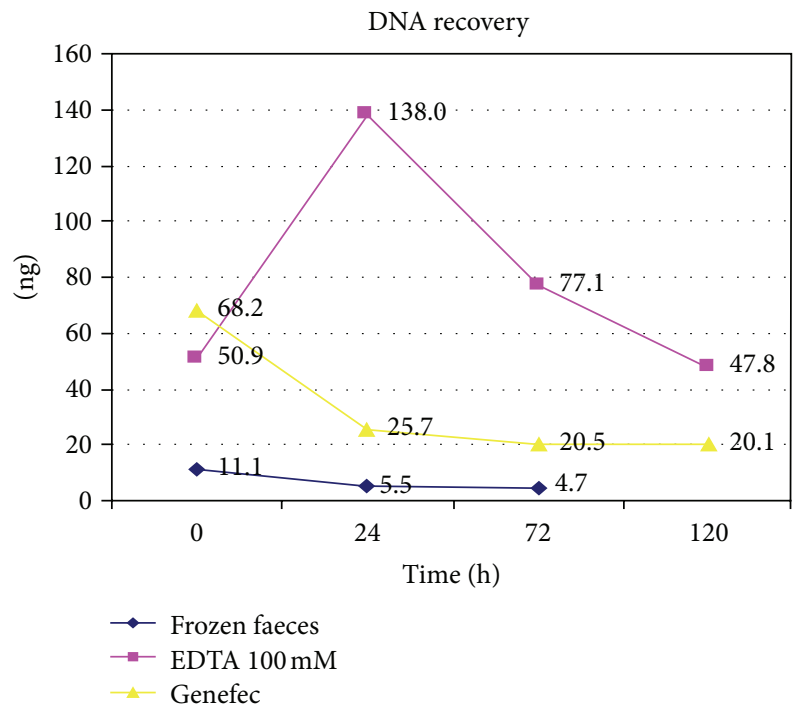

Figure 2: Results of human DNA quantification, expressed in ng, for seven samples incubated with or without stabilization buffer.

DNA recovered at $0 \mathrm{H}$ (i.e., within 2 hours after collection) (Figure 2).

\subsection{Amplificability and Integrity of Human Genomic DNA.} We determined the presence of risen molecular weight template DNA by amplified fragments between $157 \mathrm{bp}$ to 343 bp target sequences (Table 2), using DNA stool extracted from fresh and stabilized faeces of six different samples (Table 3). Although we observed differential amplification, all samples contained the shorter fragment $(157 \mathrm{bp}, 219 \mathrm{bp}$, $233 \mathrm{bp}, 271 \mathrm{bp}$, and $288 \mathrm{bp}$ ). Differential amplification was seen, when $a>300 \mathrm{bp}$ PCR product was amplified. Figure 3 shows differences in gel electrophoresis amplification in samples amplified with primers to detect fragment of $343 \mathrm{bp}$ in the Kras gene.
TABLE 3: Storage conditions for each faecal sample.

\begin{tabular}{lc}
\hline A & Fresh faeces \\
B & Buffer EDTA $100 \mathrm{mM}$ \\
C & Buffer Genefec \\
\hline
\end{tabular}

In five of six samples analyzed $\left(\mathrm{N}^{\circ} 1, \mathrm{~N}^{\circ} 2, \mathrm{~N}^{\circ} 3, \mathrm{~N}^{\circ} 4\right.$, and $\mathrm{N}^{\circ} 6$ ), DNA amplification was significantly reduced in aliquot $\mathrm{A}$ (fresh faeces), while aliquots stored in stabilization buffer ( $B$ and $C$ ) showed higher bands intensity. In these samples best amplification was present in $\mathrm{C}$ aliquots (Buffer Genefec). Likewise the addition of buffer to samples, prior to room temperature incubation was found to yield a significant increase in DNA integrity, relative to the matched aliquots with no buffer added.

3.4. PCR Inhibitors. Because stool could contain PCR inhibitors [27,37], this could affect efficiency of PCR reaction. To check whether assay accuracy was affected by potential PCR inhibitors, $500 \mathrm{pg}$ and $5 \mathrm{ng}$ human genomic DNA were added into 12 different stool DNA samples (4 unpreserved frozen stool samples, 4 stored in EDTA $100 \mathrm{mM}$, and 4 stored in Buffer Genefec). The mean recovery concentration confirms the absence of interference by PCR inhibitors both when $500 \mathrm{pg}$ or $5 \mathrm{ng}$ of human genomic DNA was added ( $P=0.7938$, and $P=0.1429$, resp.) for all storage systems (data not shown).

\section{Conclusion}

The ability to recover human DNA from stool samples and identify DNA alteration associated with colorectal cancer has been shown by several groups over the last decade. Stool sample analysis offers a noninvasive opportunity to exfoliate epithelial cell markers for colorectal cancer risk. However, one of the major obstacles of introducing faecal markers in population studies has been the difficulty in collecting adequate samples for assays from a large number of subjects. This difficulty is exacerbated by the fact that standard faecal collection procedures require fresh or frozen samples, which limits their application in a community-based setting. As a result, epidemiological studies utilizing faecal specimens have often been limited in the number of study subjects and in controlling potential confounders. Faecal self-collection kits have recently been used in large-scale epidemiological studies, but these kits lacked any DNA preservation method, potentially limiting their full usefulness [38]. Since new technologies have become available to preserve DNA for a period of time at room temperature, application of such technologies to faecal samples may have great potential for epidemiological studies. In fact, in all cases, one of the central challenges is to preserve the integrity of human DNA in the hostile stool environment, particularly during sample recovery and transport, in order to be able to amplify and interrogate the DNA for known cancer related abnormalities. Nucleases that are active in stool have the potential to rapidly degrade DNA, including the minor human DNA component, and measures must be taken to minimize their 
$\begin{array}{llllllllllllllllllll}1 \mathrm{~A} & 1 \mathrm{~B} & 1 \mathrm{C} & 2 \mathrm{~A} & 2 \mathrm{~B} & 2 \mathrm{C} & 3 \mathrm{~A} & 3 \mathrm{~B} & 3 \mathrm{C} & 4 \mathrm{~A} & 4 \mathrm{~B} & 4 \mathrm{C} & 5 \mathrm{~A} & 5 \mathrm{~B} & 5 \mathrm{C} & 6 \mathrm{~A} & 6 \mathrm{~B} & 6 \mathrm{C} & \mathrm{K}+ & \mathrm{K}-\end{array}$

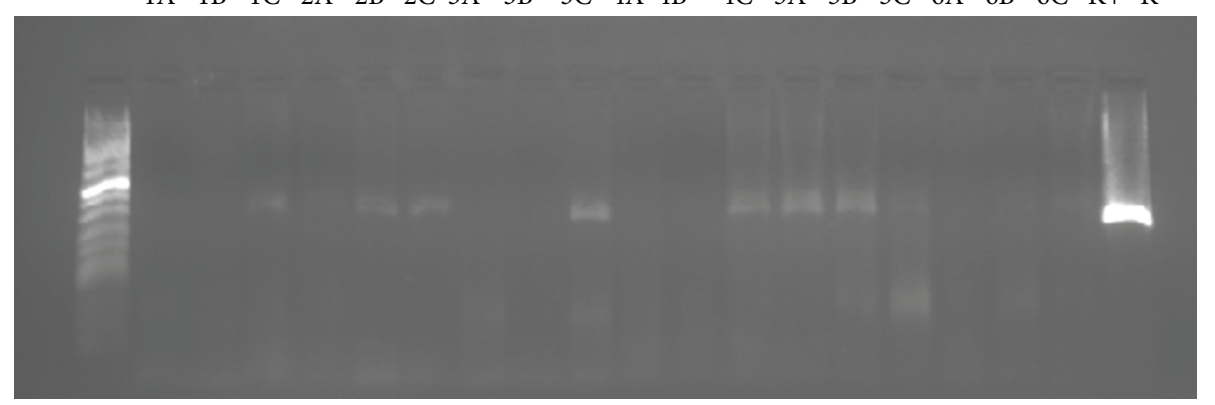

Figure 3: Differences in gel electrophoresis amplification in four samples amplified with primers to detect fragment of 343 bp in the RAS gene. Samples $\mathrm{N}^{\circ} 1, \mathrm{~N}^{\circ} 2, \mathrm{~N}^{\circ} 3, \mathrm{~N}^{\circ} 4$, and $\mathrm{N}^{\circ} 6$ showed reduced DNA amplification in aliquot A (fresh faeces). Only sample $\mathrm{N}^{\circ} 5$ shows a very intensive band in aliquot $\mathrm{A}$. In these samples, aliquots stored in stabilization buffer (B and $\mathrm{C}$ ) showed higher bands intensity with best amplification C aliquots (Buffer Genefec).

negative impact [33]. In the present feasibility study, multiple methods for faecal preservation were tested. Since the major problems with complex samples such as faeces are the yield in human genomic DNA, human DNA integrity, and presence of PCR inhibitors, analytical methods were designed to detect, quantify, and identify conditions under which this bias is minimal. The goals of this investigation were to establish how sample handling conditions affect the stability of DNA in stool, thereby potentially limiting clinical sensitivity, to determine conditions to ameliorate DNA degradation, and to investigate methods that may be used to optimize clinical sensitivity.

The first phase of the study was run comparing paired samples aliquots collected in different stabilization buffer. Samples size was chosen on the basis of previous study (Olson et al. and Nechvatal et al.), on DNA stabilization that analyzed six and fifteen samples, respectively [33, 34]. Quantitative real-time PCR data for paired aliquots shows that the amount of recoverable DNA varies considerably when comparing samples collected in preservation buffer and unpreserved. In particular, two of the six stabilization buffers tested in this study have been claimed to preserve human DNA from degradation, EDTA $100 \mathrm{mM}$ and Genefec Buffer. Very similar data were obtained by Zou et al. [37].

The second phase of the study aims to investigate the ability of preservative buffer to prevent DNA degradation and asses DNA amplificability and the potential to use faecal DNA as test in population-based screening application.

Quantitative real-time PCR data for paired aliquots shows that the amount of recoverable DNA in frozen unpreserved faeces is negatively affected by storing stool samples at $4^{\circ} \mathrm{C}$ for $\geq 24 \mathrm{~h}$. Very similar results were obtained from Olson et al. [33], using a series of 6 samples incubated at room temperature without addition of stabilizing buffer and frozen at $0 \mathrm{H}, 36 \mathrm{H}, 48 \mathrm{H}, 72 \mathrm{H}$, a significant decrease of human DNA recovered was observed.

At the same time our results showed that buffer maintains a greater sample stability over time and that the absolute best performance is obtained with $100 \mathrm{mM}$ EDTA buffer frozen on $24 \mathrm{H}$.

Data in literature shows that the human DNA extracted from fresh faeces, even if frozen in a relatively short time (within 24 hours of collection), is fragmented [33]. Results of PCR amplifications, to evaluate the integrity of the DNA extracted from fresh faeces using primer pairs that amplify fragments of different sizes ranging between the $157 \mathrm{bp}$ and $343 \mathrm{bp}$, showed that DNA amplification was significantly reduced in samples $A$, while samples stored in stabilization buffer ( $B$ and $C$ ) gave higher bands intensity. Likewise the addition of buffer to samples prior to room temperature incubation was found to yield a significant increase in DNA stability and integrity without PCR inhibition, relative to the matched aliquots with no buffer added.

Considerable scientific interest continues for the development of an accurate, reliable, easy-to-use, and affordable test for the early detection of both advances adenomas and early colorectal cancer. Advanced in faecal immunochemical test, DNA, and other molecular marker detection methods, as well as novel endoscopic imaging techniques, are being developed largely in competition with each other. In Italy screening programs offer a faecal immunochemical test followed by a colonoscopy if positive. Future direction could evaluate the use of faecal DNA markers as screening test or as the second step process such as to identify those subjects that have a high suspicion of an abnormality to undergoing colonoscopy after an FOBT positive result [39]. The principal reasons for offering two-step screening include affordability, simplicity, and probably greater public acceptability. In practice it may be reasonable to offer an inexpensive test, such as a faecal immunochemical test, with sensitivity for cancer range from $68 \%$ to $85 \%$ [40].

To make this approach possible, we need to collect adequate samples to use for molecular assay. In effort to apply faecal DNA analysis as a CRC screening modality, a scheme for preanalytical quality assurance would be of considerable value. Some aspects of this scheme would include stability of DNA samples and analysis and optimization of samples collection, shipping and storage conditions. Our studies show that samples collected in a stabilization solution stabilize the DNA so that intact nucleic acids indicative of diseased cells are more effectively detectable in the molecular assay. The combination of preanalytical methods, as DNA buffer preservation and storage conditions could be useful to guarantee the most consistent yield of relatively inhibitor free DNA. 
The addition of stabilization buffer to stool samples prior to transport presents an easily implemented solution that appears to be highly effective. Overall DNA extracts from faeces after buffer addition can easily for analysis leading to increased assay sensitivity.

\section{Conflict of Interests}

All authors of the paper do not have a direct financial relation with the commercial identity mentioned in the paper that might lead to a conflict of interests.

\section{References}

[1] Y. Koga, M. Yasunaga, S. Katayose et al., "Improved recovery of exfoliated colonocytes from feces using newly developed immunomagnetic beads," Gastroenterology Research and Practice, vol. 2008, Article ID 605273, 7 pages, 2008.

[2] S. J. Winawer, A. G. Zauber, M. N. Ho et al., "Prevention of colorectal cancer by colonoscopic polypectomy. The national polyp study workgroup," New England Journal of Medicine, vol. 329, no. 27, pp. 1977-1981, 1993.

[3] J. D. Hardcastle, J. O. Chamberlain, M. H. Robinson et al., "Randomised controlled trial of faecal-occult-blood screening for colorectal cancer," The Lancet, vol. 348, no. 9040, pp. 14721477, 1996.

[4] O. Kronborg, C. Fenger, J. Olsen, O. D. Jørgensen, and O. Søndergaard, "Randomised study of screening for colorectal cancer with faecal-occult-blood test," The Lancet, vol. 348, no. 9040, pp. 1467-1471, 1996.

[5] J. V. Selby, G. D. Friedman, C. P. Quesenberry Jr., and N. S. Weiss, "A case-control study of screening sigmoidoscopy and mortality from colorectal cancer," New England Journal of Medicine, vol. 326, no. 10, pp. 653-657, 1992.

[6] P. A. Newcomb, R. G. Norfleet, B. E. Storer, T. S. Surawicz, and P. M. Marcus, "Screening sigmoidoscopy and colorectal cancer mortality," Journal of the National Cancer Institute, vol. 84, no. 20, pp. 1572-1575, 1992.

[7] S. H. Itzkowitz, L. Jandorf, R. Brand et al., "Improved fecal DNA test for colorectal cancer screening," Clinical Gastroenterology and Hepatology, vol. 5, no. 1, pp. 111-117, 2007.

[8] G. Castiglione, M. Zappa, G. Grazzini et al., "Screening for colorectal cancer by faecal occult blood test: comparison of immunochemical tests," Journal of Medical Screening, vol. 7, no. 1, pp. 35-37, 2000.

[9] T. Morikawa, J. Kato, Y. Yamaji, R. Wada, T. Mitsushima, and Y. Shiratori, "A comparison of the immunochemical fecal occult blood test and total colonoscopy in the asymptomatic population," Gastroenterology, vol. 129, no. 2, pp. 422-428, 2005.

[10] L. G. van Rossum, A. F. van Rijn, R. J. Laheij et al., "Random comparison of guaiac and immunochemical fecal occult blood tests for colorectal cancer in a screening population," Gastroenterology, vol. 135, no. 1, pp. 82-90, 2008.

[11] D. A. Lieberman and D. G. Weiss, "One-time screening for colorectal cancer with combined fecal occult-blood testing and examination of the distal colon," New England Journal of Medicine, vol. 345, no. 8, pp. 555-560, 2001.

[12] J. J. Sung, F. K. Chan, W. K. Leung et al., "Screening for colorectal cancer in chinese: comparison of fecal occult blood test, flexible sigmoidoscopy, and colonoscopy," Gastroenterology, vol. 124, no. 3, pp. 608-614, 2003.
[13] T. F. Imperiale, D. F. Ransohoff, S. H. Itzkowitz, B. A. Turnbull, and M. E. Ross, "Fecal DNA versus fecal occult blood for colorectal-cancer screening in an average-risk population," New England Journal of Medicine, vol. 351, no. 26, pp. 2704-2714, 2004.

[14] D. B. Nelson, K. R. McQuaid, J. H. Bond, D. A. Lieberman, D. G. Weiss, and T. K. Johnston, "Procedural success and complications of large-scale screening colonoscopy," Gastrointestinal Endoscopy, vol. 55, no. 3, pp. 307-314, 2002.

[15] N. Segnan, C. Senore, B. Andreoni et al., "Comparing attendance and detection rate of colonoscopy with sigmoidoscopy and FIT for colorectal cancer screening," Gastroenterology, vol. 132, no. 7, pp. 2304-2312, 2007.

[16] S. Halligan, D. G. Altman, S. A. Taylor et al., "CT colonography in the detection of colorectal polyps and cancer: systematic review meta-analysis, and proposed minimum data set for study level reporting," Radiology, vol. 237, no. 3, pp. 893-904, 2005.

[17] P. J. Pickhardt, J. R. Choi, I. Hwang et al., "Computed tomographic virtual colonoscopy to screen for colorectal neoplasia in asymptomatic adults," New England Journal of Medicine, vol. 349, no. 23, pp. 2191-2200, 2003.

[18] C. D. Johnson, M.-H. Chen, A. Y. Toledano et al., "Accuracy of CT colonography for detection of large adenomas and cancers," New England Journal of Medicine, vol. 359, no. 12, pp. 1207-1217, 2008.

[19] D. H. Kim, P. J. Pickhardt, A. J. Taylor et al., "CT colonography versus colonoscopy for the detection of advanced neoplasia," New England Journal of Medicine, vol. 357, no. 14, pp. 1403-1412, 2007.

[20] D. Burling, S. Halligan, A. Slater, M. J. Noakes, and S. A. Taylor, "Potentially serious adverse events at CT colonography in symptomatic patients: National survey of the United Kingdom," Radiology, vol. 239, no. 2, pp. 464-471, 2006.

[21] M. Zorzi, F. Falcini, C. Fedato et al., "Screening for colorectal cancer in Italy: 2006 survey," Epidemiologia \& Prevenzione, vol. 32, supplement 1, no. 2, pp. 55-68, 2008.

[22] G. Grazzini, G. Castiglione, C. Ciabattoni et al., "Colorectal cancer screening programme by faecal occult blood test in tuscany: first round results," European Journal of Cancer Prevention, vol. 13, no. 1, pp. 19-26, 2004.

[23] N. K. Osborn and D. A. Ahlquist, "Stool screening for colorectal cancer: molecular approaches," Gastroenterology, vol. 128, no. 1, pp. 192-206, 2005.

[24] A. Loktionov, "Cell exfoliation in the human colon: myth, reality and implications for colorectal cancer screening," International Journal of Cancer, vol. 120, no. 11, pp. 2281-2289, 2007.

[25] C. H. Klaassen, M. A. Jeunink, C. F. M. Prinsen et al., "Quantification of human DNA in feces as a diagnostic test for the presence of colorectal cancer," Clinical Chemistry, vol. 49, no. 7, pp. 1185-1187, 2003.

[26] H. Matsushita, Y. Matsumura, Y. Moriya et al., "A new method for isolating colonocytes from naturally evacuated feces and its clinical application to colorectal cancer diagnosis," Gastroenterology, vol. 129, no. 6, pp. 1918-1927, 2005.

[27] D. Calistri, C. Rengucci, A. C. Gardini et al., "Fecal DNA for noninvasive diagnosis of colorectal cancer in immunochemical fecal occult blood test-positive individuals," Cancer Epidemiology Biomarkers and Prevention, vol. 19, no. 10, pp. 2647-2654, 2010.

[28] C. Rengucci, P. Maiolo, L. Saragoni, W. Zoli, D. Amadori, and D. Calistri, "Multiple detection of genetic alterations in tumors 
and stool," Clinical Cancer Research, vol. 7, no. 3, pp. 590-593, 2001.

[29] D. Calistri, C. Rengucci, C. Molinari et al., "Quantitative fluorescence determination of long-fragment DNA in stool as a marker for the early detection of colorectal cancer," Cellular Oncology, vol. 31, no. 1, pp. 11-17, 2009.

[30] K. A. Boynton, I. C. Summerhayes, D. A. Ahlquist, and A. P. Shuber, "DNA integrity as a potential marker for stool-based detection of colorectal cancer," Clinical Chemistry, vol. 49, no. 7, pp. 1058-1065, 2003.

[31] W. S. Samowitz, M. L. Slattery, J. D. Potter, and M. F. Leppert, "BAT-26 and BAT-40 instability in colorectal adenomas and carcinomas and germline polymorphisms," American Journal of Pathology, vol. 154, no. 6, pp. 1637-1641, 1999.

[32] O. Buhard, F. Cattaneo, F. W. Yick et al., "Multipopulation analysis of polymorphisms in five mononucleotide repeats used to determine the microsatellite instability status of human tumors," Journal of Clinical Oncology, vol. 24, no. 2, pp. 241-251, 2006.

[33] J. Olson, D. H. Whitney, K. Durkee, and A. P. Shuber, "DNA stabilization is critical for maximizing performance of fecal DNAbased colorectal cancer tests," Diagnostic Molecular Pathology, vol. 14, no. 3, pp. 183-191, 2005.

[34] J. M. Nechvatal, J. L. Ram, M. D. Basson et al., "Fecal collection, ambient preservation, and DNA extraction for PCR amplification of bacterial and human markers from human feces," Journal of Microbiological Methods, vol. 72, no. 2, pp. 124-132, 2008.

[35] R. Deuter, S. Pietsch, S. Hertel, and O. Muller, "A method for preparation of fecal DNA suitable for PCR," Nucleic Acids Research, vol. 23, no. 18, pp. 3800-3801, 1995.

[36] S. Onouchi, H. Matsushita, S. Nomura, T. Minowa, and Y. Matsumura, "PCR-based assessment of the recovery rate of exfoliated colonocytes or cancer cells from fecal samples depends on the storage conditions after defecation," Journal of Gastrointestinal and Liver Diseases, vol. 16, no. 4, pp. 369-372, 2007.

[37] H. Zou, J. J. Harrington, K. K. Klatt, and D. A. Ahlquist, "A sensitive method to quantify human long DNA in stool: relevance to colorectal cancer screening," Cancer Epidemiology Biomarkers and Prevention, vol. 15, no. 6, pp. 1115-1119, 2006.

[38] T. F. Jones, S. N. Bulens, S. Gettner et al., "Use of stool collection kits delivered to patients can improve confirmation of etiology in foodborne disease outbreaks," Clinical Infectious Diseases, vol. 39, no. 10, pp. 1454-1459, 2004.

[39] B. Levin, "Molecular screening testing for colorectal cancer," Clinical Cancer Research, vol. 12, no. 17, pp. 5014-5017, 2006.

[40] G. P. Young and P. Rozen, "Fecal immunochemical tests for haemoglobin (FITs): a paradigm shift in non-invasive fecal screening tests for colorectal cancer," World Gastroenterology News, no. 2, 2006. 


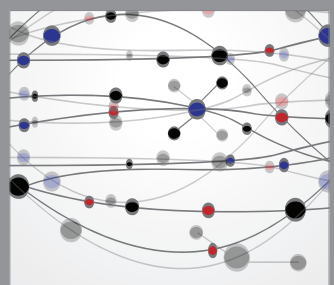

The Scientific World Journal
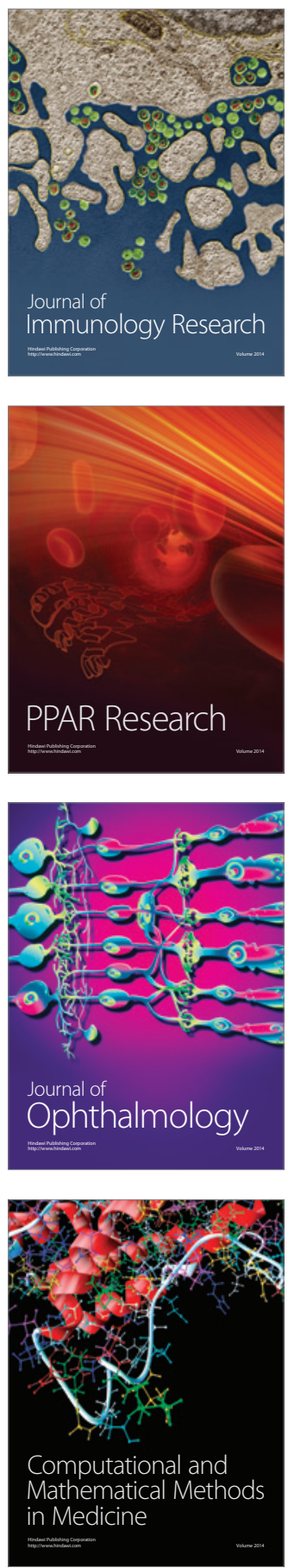

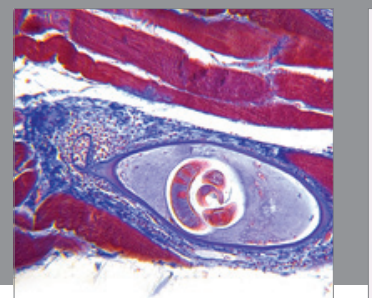

Gastroenterology

Research and Practice
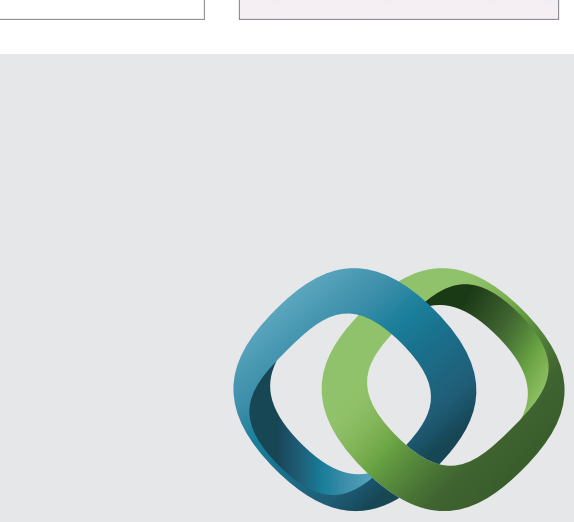

\section{Hindawi}

Submit your manuscripts at

http://www.hindawi.com
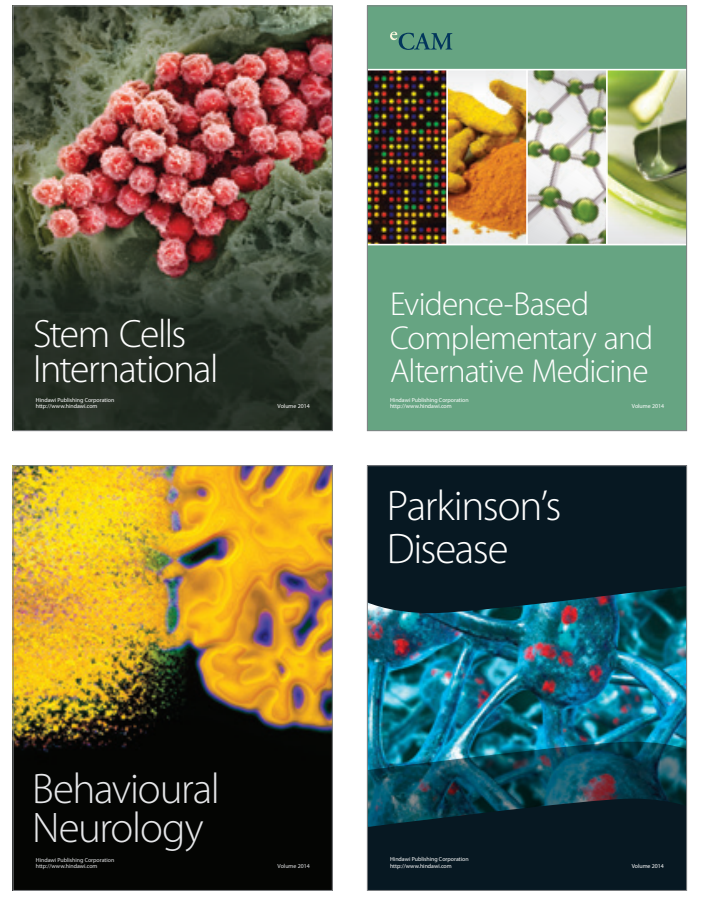
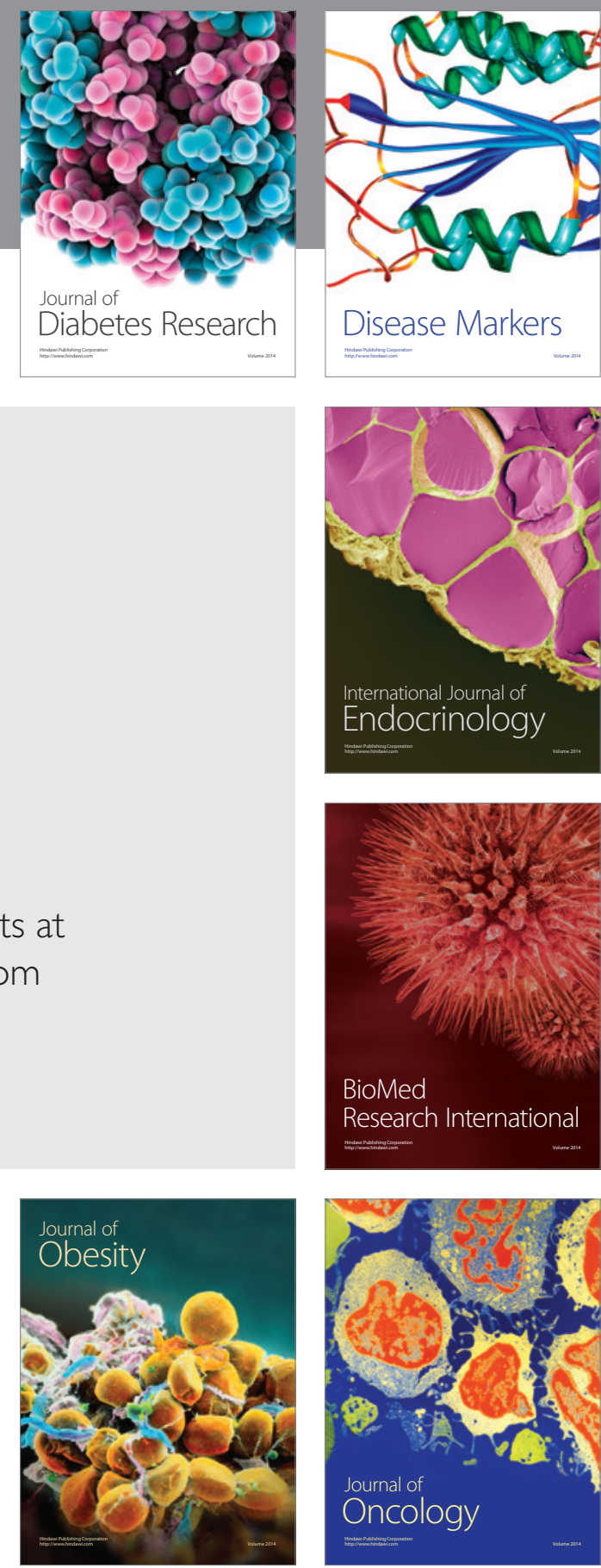

Disease Markers
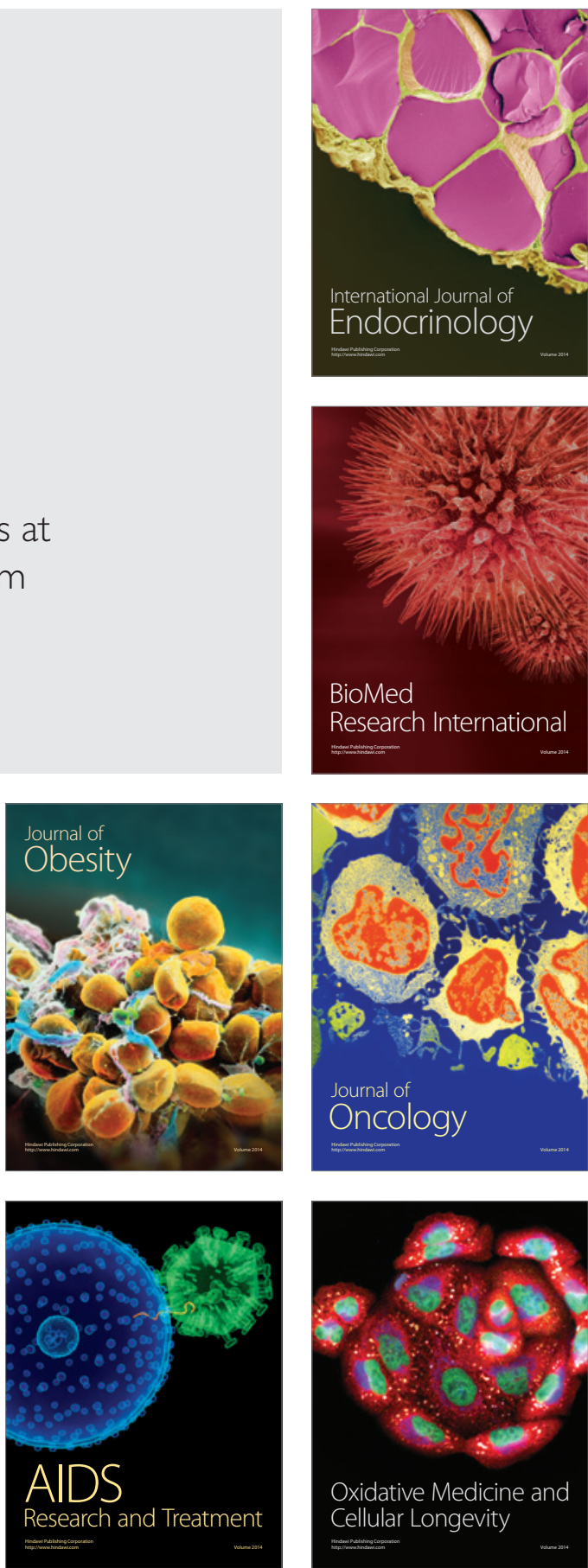